\title{
Social Media Usage for Supporting Learning Process in Higher Education: Student's Perspective
}

\author{
$1^{\text {st }}$ Munirul Abidin ${ }^{1}$ \\ \{munirul@bio.uin-malang.ac.id ${ }^{1}$ \} \\ Universitas Islam Negeri Maulana Malik Ibrahim, Malang, Indonesia ${ }^{1}$
}

\begin{abstract}
This study aimed to describe the use of social media to support the learning process in higher education from student perspective. This study describes how the use of social media among students and what benefit they got from the use of social media for their learning in the college. This study used a mixed method; quantitative and qualitative approaches together. The quantitative analysis employed to describe the students' perceptions of the use of social media in their learning activities and qualitative analysis is used to analyze the data obtained through interviews with several students who have been selected as a Focus Group Discussion (FGD) to ensure the quantitative findings. This study found that the use of social media is a trend that can't be avoided in today's world of higher education. Social media provides a major contribution in supporting the student learning activities.
\end{abstract}

Keywords: social media, higher education, high technology, focus group discussion, social media benefit.

\section{Introduction}

Now days, adoption of many types of technologies in higher education become an established trend. Academician has realized that the use of technology in higher education context become more important in present time [1]. Teachers have pushed to be able to keep up with the technological knowledge of their students [2], who quite competent and dependent to the computer and other online instruments [3]. This included digital communication technologies [4] and web technology [5].

In the past, computer was determined as the need of classroom technology [6], but today adult learners and also their instructors carry powerful digital communication technologies with them everywhere they go [4]. In today's classroom, laptops have started to take the second row to allow space for smartphones, tablets, and other mobile devices to take place [7]. Since digital communication technology, especially mobile technology, today have features that are comparable but far more dynamic ways than a personal computer, majority internet users used this to conduct their online activities. Data showed that sales of mobile technology to end users increase quarterly every year. The most common mobile technology used for communication is social media. Research found that the sixth of top ten most-used mobile apps globally are social media apps [8].

The fast-growing of social media and the entrance of mobile communication technology in the community of higher education presented a unique challenge for academician and researchers to examine and explore this exciting development. Since it is suggested that social 
media has revolutionized the way people interact and communicate [9] and provides new opportunities both for increased participation and to change the way people learn [3] they tried to examine this trend using among college in the university [10]. The trend of using social media among university students seems to be increasing day by day particularly at higher education level for interactions and communication usage [11].

Moreover, this explosive popularity also interest universities to reflect critically on its use. They explore this success to include offline results such as student engagement, and increased participation. The study did by Heiberger \& Harper [12] and Hurtado [13] found a positive correlation between social networking website use and college student engagement. Not just student engagement, the study also found that social media can increase interactivity. Concerning in the effectiveness of the use of social networks in attitudinal training courses, study did by Ortega [14] demonstrate that students who used social media tools participated 11 times more in discussion and obtained better learning outcomes than those who did not. They also explore the value of social media technology for higher education institutions. Combine with the mobile technology they explore many possibilities of the use of social media technology in institutions. Academicians propose social media are promising technologies to support and enhance teaching-learning processes, supporting marketing tool for retaining and attracting new students and supporting administrative services.

However, although many researchers have suggested social media as powerful resources for teaching-learning and the need of adopting mobile technology in education, many of them also remain the student and faculty's laggard when it comes adopting these technology innovations. For example study conducted by Rodríguez [15] on the effect of the usage of a social network site (SNS) (www.grouply.com) for a class related group project on the development of individual abilities and performance in group work at an intermediate macroeconomic class at a Spanish university. The results indicated the negative impacts of SNS usage for group projects because although students are in general attracted by the idea of social media, but they didn't familiar with that tools. Those examples give insight that there are technology characteristics that must be considered to higher rates of acceptance by both students and faculty. In this case, the faculty has to understand what the most prominent mobile technology and social media tools that students have been using.

Such broad presentation of social media usage above present a relevant facts about the fast-growing aspect of student's communication patterns and emphasize that social media has been studied on different level. However, since the massive and rapid development of social media via mobile technology, there seems the necessity to make advancements studies in this fields to provide frequently insight of trend and development of social media usage among students in the higher education context. It is critical to examine what and how students of higher education institutions practiced using social media for their academic activities. This study aimed to explore the trend of social media usage among master student program and what benefit they get of using it to facilitate their education activities. The result may help university both to understand the trend of using social media among student and to inform the best social media tool for university to connect with and facilitated student academic success.

\section{Research Method}

This study employed both quantitative and qualitative approaches. The survey was conducted to examine the trend of using social media among students of the university, while 
focus group discussion was conducted for data triangulation. A questionnaire was constructed and employed to collect data. Participant of this study were the master student studying in Islamic Education Management Program at UIN Maliki Malang, Indonesia. The population of the study was 329 students, who still take a course in the first, second and third semester. 200 questionnaires distributed to students randomly and invite 10 students to be the informants of FGD. A total 167 filled questionnaires were good for the next analysis. FGD, on the other hand, was conducted with 10 selected participants, who used social media daily via mobile devices, such as smartphone and tablet. The purposes of FGD were both for confirming of survey data and to explore what was the benefit of social media toward their academic activities.

\section{Results and Discussions}

A total 167 master students responded to the survey. The respondent comprised of 91 males $(54 \%)$ and 76 females (46\%). This data of survey findings then are presented together with the findings obtained from focus group discussion with 10 participants.

\subsection{Student Familiarity With Social Media}

The first question of the survey is intended to investigate student knowledge about the social media concept. As seen at table 1, overall $100 \%$ of students were familiar with social media at varying different levels. Even, $70 \%$ of students were very familiar with social media and $20 \%$ of students familiar and $10 \%$ little familiar with social media.

Table 1. Student Familiarity With Social Media

\begin{tabular}{|c|c|c|}
\hline Familiarity & $\mathrm{N}$ & $\%$ \\
\hline Not at all familiar & 0 & $0 \%$ \\
\hline Somewhat familiar & 17 & $10 \%$ \\
\hline Familiar & 34 & $20 \%$ \\
\hline Very familiar & 116 & $70 \%$ \\
\hline Total & 167 & $100 \%$ \\
\hline
\end{tabular}

For a better understanding of this familiarity, the students were asked regarding the device that they use to the online activity of using social media. Most of the master students access social media account via mobile devices such as the laptop $(20 \%)$; tablet $(15 \%)$ and the biggest was via phone $(65 \%)$. It can be concluded that all student familiar with social media, in which more than half of them use the mobile phone to access it.

The qualitative data confirmed the survey outcome in term of their habit in using social media via the mobile device. They explained:

"I am very familiar with social media because I need and used it in everyday life to communicate with my family and my friends, especially in the group..."

"I choose to use smartphone for my networking activity. It makes me easy to move anywhere, while I still can continue to online anytime... and uses social media to communicate and share anything in the group or just with someone”. 
Social media has given many facilities that make our communication more effective in time and money. We can know something new faster. We can share new thing faster too. For me..."

"Using social media via smartphone is a way of life. You know...we can take in our pocket, so easy to online anytime. When we have free time or boring with our task, we can just open our phone and say hai to our friend...or sometimes I share what I was done and upload photo.

From those quotes can be concluded that what makes students familiar with social media is because they need it, especially for communication. Combine with the mobile device (such as smartphone and tablet), social media has become students' way of life. It means that basically social media has come to fulfil the simple basic of human desire that is the need to connect or be a part of a group of other humans.

\subsection{Frequency of Using Social Media}

It is interesting that one of master student states that they use social media via smartphone as the way of life, besides for communication. This reason then contributes to support the next result of the survey finding of the frequency of use of social media interface by master students (table 2). In order to obtain the frequency of using social media, an expressed question was asked: 'How often have you used social media?'. The answer showed that most of the master students $(79 \%)$ used social media on the daily basis, few students $(16 \%)$ used in weekly basis, and only $4 \%$ use in monthly basis.

Table 2. Frequency Of Using Social Media

\begin{tabular}{|c|c|c|}
\hline Frequency & $\mathrm{N}$ & $\%$ \\
\hline Never & 0 & $0 \%$ \\
\hline Every day & 132 & $79 \%$ \\
\hline Several times a week & 26 & $16 \%$ \\
\hline Several times a month & 7 & $4 \%$ \\
\hline Less often & 2 & $1 \%$ \\
\hline Total & 167 & $100 \%$ \\
\hline
\end{tabular}

Data from FGD indicated that some of the master students seem that they take social media as necessity in their life. For example, some participants of FGD explained their frequency of using social media as following quotes;

"Every day I check my social media. If I have free time, I will see my social media for seeing what new information in my groups, or just for changing my display picture or my status. I will be sad if my internet connection was poor"

"I need social media in my daily activities. I check it every day. It makes me feel have many friends ...even if I am alone in some places, such as at home."

"Social media is like a home for me...I can do more and more with social media. Chatting, sharing, gaming, and many else we can do with social media. I used it every day because I need it. But, when I feel need to focus on some projects... I make limitation to access my social media."

\subsection{Social Media Engagement}

Survey also trying to explore how many social media accounts that student has engaged. The answer indicates that $84 \%$ of students have engaged at least with three social media 
account. As seen in table 3, 54\% have three accounts, and 30\% have more than three accounts. Only a few of them have two $(13 \%)$ or one $(4 \%)$ account. Some student trying to explain why they engage many social media accounts, as quotes follow;

"in the past...I just engage one social media sites, i.e facebook, and I check it just twice a week. But then I have a smartphone and begin to trying many social media application. For now, I have installed four applications in my phone: Facebook, WhatsApp, BBM, and telegram. I like to try the new one of social media application".

"actually... I have three social media application because of my necessity to keep in touch with many of my friends and my family, especially in my class and my work. Most of my friends in my class using WhatsApp for group communication, so I install it.

Table 3. Student Engagement Of Social Media

\begin{tabular}{|c|c|c|}
\hline Frequency & $\mathrm{N}$ & $\%$ \\
\hline None & 0 & $0 \%$ \\
\hline One & 7 & $4 \%$ \\
\hline Two & 23 & $13 \%$ \\
\hline Three & 97 & $54 \%$ \\
\hline More than three & 54 & $30 \%$ \\
\hline Total & 167 & $100 \%$ \\
\hline
\end{tabular}

For better understanding what social media sites or application that student has engaged, researcher asked the participant to list the name of social media that they have engaged. The answer display that all of the informants have WhatsApp and Facebook (10 participants), 8 informants have 'BBM' and 'Facebook messenger', 5 informants have 'Twitter', 3 informants have 'Instagram' and few of them have 'Line' application (2). This result then demonstrate that most of the social media applications that student use basically is for communication.

Keep in touch with this finding, the participant of FGD also asked to count how many group community they follow in their social media account. In line with the amount of social media they engage, most of the participant ( 8 peoples) said that they have at least three group communities. When clarifying in the discussion, some students state their reason as follow:

"I follow four groups of social media, especially in WhatsApp...two of them were the old friend from my past education in high school and university, while others were my family and workgroup. It is very helpful for me to find any information that I need. My friend in my group will share it fastly."

"I join the group on my facebook for my hobby...music community. Other was in WhatsApp and BBM for communication in a group. I need those groups for getting and sharing much information."

"We can't ignore the necessity to follow several groups, such as class, alumni, work, and family. Class group is the most important we should follow. We need to always get new information about academic activities. Alumni group is important to build a network to get possibility of many opportunities in our life. Family group, no less important is to communicate with them whenever and wherever we are".

\subsection{Benefit of Social Media for Learning Activities}

The last question of the survey is asking to the students about the most benefit of social media use for their daily activities in the classroom. As seen in table 4, the results do not indicate the salience of one of the benefits. However, many students $(28 \%)$ placed 'supporting 
academic and learning activities' as the most benefit of social media use for their learning daily activities. $17 \%$ students getting the benefit for pleasure, enjoyment, and for killing the time, $12 \%$ for searching and making friends, and $11 \%$ for build networking. Few of them feel benefit for 'getting information' (7\%), and sharing and discuss new ideas, issues and events with community $(4 \%)$.

To confirm and enlarge the survey findings, group discussion then asked to explain the benefit of social media in supporting their learning and academic activities. They give expression as follows:

"We have used social media for many class activities such as discussion on task distribution, rescheduling class meeting, and sharing much information. With group, it is more effective to coordinate many class activities"

"Sometimes we discuss hot topics and new material of some subject. We are sharing possibility of reference source since we sometimes don't have time to go to the library."

"Since our library has limited source of book or journal... We find many sources from internet and then share it to our friend in WhatsApp group... all student in my class follow the WhatApp class group.

"Social media help us very much to coordinate the class activity. Sometimes, our professor can't attend the class for particular reason...or suddenly we must move to other classrooms because the room has been used by other class.

"By using social media, we get new information fastly and simultaneously. Our class leader informs new announcement, news and information as soon he gets from the university. So do with all members in the class. Anyone who gets new information or announcement will distribute to the group class in social media."

Table 4. Benefit of Social Media Use

\begin{tabular}{|c|c|c|}
\hline Benefit & N & $\%$ \\
\hline Communicating with Lecturers & 35 & $21 \%$ \\
\hline Searching and making friends & 20 & $12 \%$ \\
\hline $\begin{array}{c}\text { Supporting academic and learning } \\
\text { activities }\end{array}$ & 47 & $28 \%$ \\
\hline Build networking & 19 & $11 \%$ \\
\hline Killing the time and pleasure & 29 & $17 \%$ \\
\hline $\begin{array}{c}\text { Sharing and discuss new ideas, } \\
\text { issues, and events with community }\end{array}$ & 6 & $4 \%$ \\
\hline Getting information & 11 & $7 \%$ \\
\hline Total & 167 & $100 \%$ \\
\hline
\end{tabular}

Those expressions indicate that social media has the important role in student activities in the university. Not only for building a network between them but also for supporting academic and learning activities in the class, sharing information about books and references, and managing lecture activities between student and lecturer. This finding confirms the research conducted by DeAndrea et.al. [16] and Lee \& Lee [17] that aligns that social media usage benefit for improving student's adjustment to college and increased students' perceptions that they would have a diverse social support network during their first semester at college [18][19]. 


\section{Conclusions and Implications}

This study has resulted in many important findings. First, the finding reports the popularity of social media among masters student of the university. Majority of students were familiar with social media and use it every day online via mobile phone. Indeed, the majority have at least three accounts of social media.

The result of group discussion findings also confirms that communication using social media has being the necessity and the new way of life.

The second finding is that student has used social media to support their academic activities. Student has felt the benefit of using social media for supporting their academic activities, especially for class management, such as, discussing subject, task coordinating, rescheduling class meeting, and material planning for class discussion.

Those finding should imply some implications; first, the university has to integrate social media as a tool to assist the current educational system, i.e in management and also in teaching-learning activities. For management, they can build university group in which all students of the university can join to that group to deliver many new rules, information, invoices and so on faster and more efficient. These groups will also give two-way communication between student and university. It will give students opportunity for giving their opinion about the goodness or the badness about university, and also give university to listen what student wants. Usually, the student has to visit university website for knowing the new information. It means that students must be active to know the new one. If management uses social media and builts social group in which all student must join on that group, they can deliver any new information via social media and engage their students until student becoming alumni.

For teaching-learning, social media can be used to assist the process of curriculum delivery. If student and lecturer join together in one group, it will give extended teachinglearning process. There will be two-way communication anytime and anyplace between student and lecturer. They can together discuss materials, schedules, tasks, references, etc. without limitation in time and place.

The finding also shows the most popular social media being used by the student in Indonesia was WhatsApp. All participant of FGD states that they have Facebook and WhatsApp used to support their educational activities. This finding might be helping the university to find the appropriate social media tool to integrate with the educational system. But the university needs to concern about features of that tools. Each social media tool or application has their own strength and weakness. University needs to make sure that social media has appropriate facilities, contents, and features for learning activities.

Finally, this study shows the huge opportunity of social media trend among university student. It means that there is the challenge for the university to keep up with this new technology trend. Whatever interesting this social media technology in education, it must be underlined that social media technology just a tool that should not replace education it's self, but assists the process of education.

Acknowledgements. This paper in conjuction with The 1st International Conference on Islam, Science and Technology (ICONIST 2018) in Malang, East Java.

\section{References}


[1] Merç, A. P. D. A.,"Using Technology in the Classroom: A Study with Turkish Pre-Service EFL Teacher," TOJET, Vol. 14 (2), 2015.

[2] Cañado, M. L. P., "English as a Foreign Language Teacher Education: Current Perspectives and Challenges", Porta Linguarum: revista internacional de didáctica de las lenguas extranjeras, Vol. 23, 2015

[3] Prensky, M., "Digital natives, digital immigrants part 1", On The Horizon, Vol 9 (5), 2001.

[4] Weidert, J. W., The mobile college community: A study of adult learners' adoption and use of digital communication technologies on the campuses of Florida's community colleges, Fielding Graduate University. 2012.

[5] Harris, A. L., \& Rea, A. "Web 2.0 and virtual world technologies: A growing impact on IS education", Journal of Information Systems Education. Vol. 20 (2). 2009

[6] Oppenheimer, T., "The computer delusion”, The Atlantic Monthly. Vol. 280 (1), 1997

[7] Roebuck, D. B., Siha, S., \& Bell, R. L., "Faculty usage of social media and mobile devices: Analysis of advantages and concerns", Interdisciplinary Journal of E-Learning and Learning Objects. Vol. 9, pp.171-192, 2013

[8] Ahmad, Irfan. The Biggest Social Media Trends of 2015. Retrived from http://www.socialmediatoday.com/social-networks/ irfan-ahmad/2015-09-25/5 -biggest-social-mediatrends-2015-infographic, 2015.

[9] Weisgerber, C., \& Butler, S., "Editor's introduction: Special issue on communication pedagogy in the age of social media", Electronic Journal of Communication, Vol. 20 (1-2), 2010

[10] Yusop, F. D., \& Sumari, M., "The use of social media technologies among Malaysian youth", International Educational Technology Conference (IETC), Kuala Lumpur, Malaysia. 2013

[11] Hussain, I., "A study to evaluate the social media trends among university students", ProcediaSocial and Behavioral Sciences. Vol. 64, 2012.

[12] Heiberger, G., \& Harper, R. Have you Facebooked Astin lately? Using technology to increase student involvement. New Directions for Student Services. 2008

[13] Hurtado, S. 2007. College freshmen and online social networking sites. Higher Education Research Institute (HERI) Research Brief. Retrieved February,5, 2009.

[14] Ortega, O. D. "Correlating students performance with social networks use in teaching". Procedia-Social and Behavioral Sciences. Vol. 93, pp.1668-1672. 2013.

[15] Rodíguez-Tejedo, I., Lara, S., Zárraga-Rodríguez, M., \& Rodríguez-Chacón,V., “An assessment of the impact of social networks on collaborative learning at college level", ProcediaSocial and Behavioral Sciences. Vol. 47, pp. 1616-1621, 2012

[16] DAdrea, David C., et al., Serious social media: On the use of scial media for improving students', 2012

[17] Le, H. Y., \& Lee, H. W., "Comparing Social Network Analysi of Posts with Couning of Posts as a Measurement of Learners' Participation in Facebook Discussions." Turkish Online Journal of Educational Technology. Vol 15 (1). 2016

[18] Banlal, S., "Exploring student teachers' perceptions of the infuence of technoloy in learning and teaching mathematics." South African Journal of Education. Vol 35 (4). Doi: 10.15700/saje.v35n4a1217, 2015

[19] Ellsn, N. B., Steinfield, C., \& Lampe, C.. "The benefits of Facbook "friends:"Social capital and college students' use of online social network sites," Journal of Computer-Mediated Communication, vol. 12 (4), pp. 1143-1168. DOI: 10.1111/j.1083-6101.2007.00367.x, 2007 